\title{
Blogging, creativity and autonomy. An attempt to have one's cake and eat it
}

\section{Alison Bouhmid}

\section{(2) OpenEdition \\ 1 Journals}

\section{Electronic version}

URL: https://journals.openedition.org/asp/6089

DOI: 10.4000/asp.6089

ISSN: 2108-6354

\section{Publisher}

Groupe d'étude et de recherche en anglais de spécialité

\section{Printed version}

Date of publication: 1 November 2019

Number of pages: $72-89$

ISSN: 1246-8185

\section{Electronic reference}

Alison Bouhmid, "Blogging, creativity and autonomy. An attempt to have one's cake and eat it", ASp

[Online], 76 | 2019, Online since 01 November 2019, connection on 01 December 2021. URL: http:// journals.openedition.org/asp/6089; DOI: https://doi.org/10.4000/asp.6089

This text was automatically generated on 1 December 2021.

Tous droits réservés 


\title{
Blogging, creativity and autonomy. An attempt to have one's cake and eat it
}

\author{
Alison Bouhmid
}

This report describes an online EFL course for second-year students at Paul Valéry University in Montpellier. Its main objective is to foster learner autonomy through creative writing on a blog. As the course is offered exclusively online, a virtual learning environment (VLE) is used (Moodle) to make course content available to students who are then expected to choose a blogging platform to set up and write their own blogs. The report thoroughly details course design and evaluation procedures and will therefore be very helpful to those willing to develop similar courses. The novelty here is that (1) the course is fully online, (2) that it aims to foster creativity and autonomy (3) and that no feedback is provided by the teacher: a combination of peer-generated feedback and participation points automatically awarded by the VLE has been favoured, in accordance with the objective of helping students develop their autonomy, their creativity but also their blogging and English language skills.

If creating a group blog can be considered as a task, that is to say a real-world activity with a specific outcome for an audience/a readership that goes beyond the language classroom, it is also an example of Computer-Supported Collaborative Writing (CSCW) which has been researched extensively in recent years with a view to developing language skills. Indeed, CSCW is supported by sociocultural theory thanks to the peer scaffolding provided during the co-construction of a text (Swain \& Lapkin 1998; Storch 2013) and by interactionist perspectives thanks to the potential feedback in context that it fosters (Gass 1997; Mackey, Abbuhl \& Gass 2012). In fact, it has been shown that learners are more likely to provide Corrective Feedback (CF) to their peers during a collaborative writing task (produced with a peer) than on a piece of writing produced by a peer because the co-construction of a text makes CF provision less facethreatening for them (Tigchelaar \& Polio 2017). However, setting group work is no guarantee that groups will truly be engaged in the provision of CF during collaborative work and that each group will thus become a true learning community: it is therefore 
necessary to investigate collaboration processes through the analysis of learner behaviour in collaboration activities (Chanier \& Cartier 2006).

Another point I would like to make about the course described is that it is not clear whether students were expected to provide feedback on language or simply on content (i.e. ideas and their organisation). Although collaborative writing potentially promotes focus on language, research shows that students tend to provide more feedback to their peers on content than on language itself (Kessler et al. 2012). However, there needs to be negotiation of meaning during collaboration for a collaborative writing task to lead to language learning, as negotiation work is what makes it possible for learners to focus on form (i.e. draw their attention to language use) and, in doing so, to notice the gap in their knowledge. In other words, there has to be a focus on language (during languagerelated episodes, also called form-focused episodes) in peer dialogue during collaboration for language learning to take place. In this respect, it should be noted that, despite what they may think, learners are often quite competent at giving appropriate $\mathrm{CF}$ to their peers, whether they are offered specific peer feedback training to do so (Tigchelaar \& Polio 2017) or not (Sarré \& Sharfizadeh forthcoming), although proficiency level appears to play a major part in feedback accuracy (Wigglesworth \& Storch 2012). In addition, it is also important to know how learners engage with the feedback they receive.

In the course described by A. Bouhmid, peer assessment is solely based on other students' output (i.e. their blogs). Even though participation points are automatically awarded by the VLE once a student takes part in a forum discussion or chat (that is to say, regardless of the quality of their participation), one simple way to give more weight to the process than to the actual outcome (i.e. the final product) would be to make sure that peer assessment also takes into account the engagement of students in the collaborative process (i.e. the way they engage in the group chats, wikis, forums, etc.) by awarding points for the learners' engagement in discussions and decisionmaking processes which lead to the final output. Ideally, it would also be worth awarding points for $\mathrm{CF}$ provision (to the giver) and for $\mathrm{CF}$ incorporation (to the receiver) in the writing phase.

Finally, two potential avenues to be explored in the future could be (1) the weight given to the "quality of English", which only amounts to $20 \%$ of the peer-assessment grade $(4 / 20)$ - isn't it a language course, after all? - and (2) whether offering this course in a blended learning format (with face-to-face sessions as well as online sessions) could help increase participation rate (which is below $50 \%$ in the current version of the course). The course designed by A. Bouhmid has enormous potential for helping students develop their autonomy and creativity, as well as their digital literacies, which are some of the objectives of the course. In this respect, this teaching report is a valuable addition to previously published contributions in the field as it provides a concrete example of how to target transferable soft skill development in an online language course. (Cédric Sarré, université Paris Sorbonne)

\section{Introduction}

1 The role of evaluation is universally recognised as being fundamental to the learning process, and the challenge, in any teaching context, is finding a form of assessment appropriate to the needs of students, the institution and its curriculum. As Collini points out, pupils are taught but students study and this implies developing the 
capacity to "challenge or extend received understanding" (2016: 9). The blogging course to be presented in this report is designed to accompany students in the development of this capacity, fostering student autonomy and creativity and reconsidering the role of evaluation in this process. The approach uses the definition of Jones and Richard regarding creativity as "using language in creative ways to solve problems, to establish or maintain relationships, and to get people to act, think or feel in certain ways" (2016:5) combined with the definition of Holec of autonomous learners as those who have "the ability to take charge of [their] learning" (1983: 3). Over the semester, students work on their English language skills, develop creativity, become increasingly familiar with the use of online collaborative tools, more practised in providing constructive feedback, editing texts, increasingly autonomous in the process of evaluation and their language learning, and evermore independent users of technologies, all valuable professional skills in many different fields. By grappling with and taking informed decisions regarding marking criteria, the aim is for students to obtain hands-on and enriching experience as they engage with the true sense of evaluation, namely the exercise of judgement.

\section{Context}

2 The learning and teaching context for the course to be presented is that of online distance English foreign language learning for second-year students who are specialists of other disciplines at Paul Valéry University of Humanities in Montpellier. Distance learning has a relatively long history at Paul Valéry University, but it wasn't until the purchase of the WebCT platform ${ }^{1}$ that distance courses were gradually transformed (between the years 2000 and 2004) from paper to online courses. In 2010, it was decided to create whole degree courses online, including transdisciplinary modules such as LSP and computer science. As far as English is concerned, for the year 2018-2019, 455 undergraduates followed a module, representing $79.5 \%$ of all undergraduates taking an online language programme. The second-year, first-semester English course, creative fiction-writing was followed by 105 students and the second-semester blogging course by 103.

\section{Course Objectives}

- Develop creativity and collaborative writing skills;

- Introduce students to blogging and develop blogging skills;

- Improve English writing skills;

- Practise digital skills, including the use of collaborative tools;

- Develop student autonomy and self-reflexive attitudes to learning;

- Develop the capacity to provide positive feedback and to re-edit texts.

\section{Course design and evaluation}

Both second-year courses are fully online and there is no face-to-face contact between students and their teacher. Each course comprises 18 teaching hours. The blogging course is a second-semester follow-on course from the first semester creative writing module Writing, both fiction and blogging, is approached through the lens of creativity 
in that students are free to choose what stories/blogs they wish to write and how they wish to write them.

4 Creativity in writing would seem to be closely linked to autonomy, as individuals feel legitimate in developing a sense of their own style, rather than simply conforming to received models and the two courses have tried, in practical terms, to promote student creativity and autonomy. This has largely been done by applying Little, Dam, and Legenhausen's criteria that is to say by 1) exploiting previous student 'knowledge, interests and skills' (2017: 1), 2) allowing students to choose course content, 3) placing evaluation at the centre of this process, 4) encouraging students to adopt a reflexive stance vis-à-vis the way in which they learn and 5) developing a sense of 'responsibility' both for their own learning and in helping their peers to learn. One of the challenges in designing these courses has been doing this within the normative framework that an accredited university course demands. Because the number of hours allotted to this type of course is obviously limited in this context, the course focuses on developing students' present and future capacity to improve their English, a focus reflected in the importance given to participation points in the final mark.

5 The fact that the blogging course is a second-semester course is important because whilst working within a different genre of writing it continues and extends the approach started with the same group of students in the first semester, notably concerning continuous assessment and peer assessment.

6 At the beginning of the first semester the course design for the fiction-writing course is made explicit to students and the way in which their work will be evaluated (see appendix 1). The continuous assessment comprises 2 participation points automatically generated by Moodle as well as two pieces of marked work. In Writing Task 1, a workshop activity, students provide feedback but no mark. In Writing Task 2, students are taken one step further and not only have to provide feedback but also a mark. Each text is marked by two other students using a marking grid that is available for students. The final mark for this task an average of the two marks. Writing Task 3 is submitted only to the teacher and is marked according to the following grid: Character ( /2) Setting ( /2) Story ( /2) Vocabulary ( /2) Grammar ( /2). This means that in the overall marking scheme the peer-generated and the teacher-generated marks have the same worth (10 points each).

7 The blogging course builds upon this first experience, for many students, of continuous and peer assessment, in such a way as to encourage self-assessment and student collaboration, not only in the grading process but also in the construction of grading criteria, thereby developing critical evaluation skills and encouraging students to take a metacognitive stance regarding their learning and writing processes. In this sense the course will be an attempt, as De Lavergne \& Lieb-Storebjerg claim, ${ }^{2}$ to apply 'a conception of learning that goes beyond the mere acquisition of technical or theoretical knowledge, but one that is realised in a new way of perceiving and understanding how we relate to the world and to knowledge in general' (2009: 406), an approach that necessarily depends upon the development of student autonomy and creativity.

8 As with the first-semester fiction-writing course, the means of course evaluation is made explicit at the beginning of the blogging course (see appendix 2). The final mark depends upon automatically generated participation points, including participation in 6 forums (18 points), 2 glossaries ( 6 points), 2 chats ( 6 points), 1 wiki (10 points). These 
are added to the peer-generated mark (20 points) given for the blog in stage 7 of the course. As will be described in more detail further on, the course is not linear. Students are constantly invited to return to previous activities, reconsider what they have learnt in the meanwhile, and build upon and enrich their previous knowledge as they become aware of their learning process. Given that the course is dedicated to developing collaborative writing and learners' awareness of how knowledge is gradually acquired, it is the process rather the final product that generates the most points in the system of evaluation.

Stages 1,2,3 (appendix 2) are introductory, putting into place the basic content and linguistic knowledge that will enable students to successfully follow the course. Students are accompanied as they learn to identify common traits of blogs, explore the extent to which these common traits are systematically present or not, think about different genres of blogs and analyse their attendant styles such as use of argumentation, anecdote, exclamations, personal point of view, invective, or conjunctions. In the first glossary writing activity, students are required to provide or edit definitions for technical blogging terms. In Forum 2 students have the opportunity to give specific examples of blogs they like and/or do not like and express their opinion about what makes a good blog. They are asked to refer back to what they write in this forum later on in the course when they start to consider grading criteria. In Forum 3 (appendix 3) students are invited to find a blog that they enjoy reading, post the link for it, discuss the genre it represents and the style used. I suggested they use the blog typology mentioned by Rivens Mompean (2010: 380), based on Cardon and DelaunayTeterel (2006), namely personal blog, familiar blog, expert blog, citizen blog, to which Rivens Mompean adds a new category, metablog.

In the middle section of the course ('From Me to Us, Without Forgetting Them') the group work and collaborative writing are put in place. To begin with, students post a text, entitled 'About Me' in a glossary. Texts are posted in alphabetical order according to students' surnames so that the glossary can later be used as a directory. In Forum 4 students discuss which subjects they would like to write a blog on (with different threads for different subjects) and decide with whom they would like to work (reading their peers' texts in the glossary in order to get to know each other better). Once they have come to a decision, they create their own work group (comprising 3 or 4 students) on Moodle which will automatically give them access to a group chat used to exchange ideas between them, privately and informally, before starting to write their collective text 'About Us', in the Wiki. Once 'About Us' is finished each student posts a copy of the text in Glossary 2 after the text that they wrote earlier entitled 'About Me'. Then, they are asked to comment upon the text of the person following them in the alphabetical glossary list. Students will thus be invited to go backwards and forwards between forum, glossary, chat and wiki. This non-linear approach, with moments for both personal and collaborative, private and public writing is designed to make space for the voices and texts of each individual student within the group work. Students will also need to negotiate meaning in their texts in accordance with interaction between the members of their blogging group, as well as revising and rewriting the collaboratively written text in accordance with feedback provided by other students.

11 In stage 5 (appendix 4), students must think about audience awareness, what public writing entails and share tips on how best to do this. It is at this stage that the grading criteria for the students' blogs are decided upon. To begin the discussion, students are 
requested to refer back to Forum 2, in which they expressed their first ideas about what makes a good or a bad blog. They then reflect upon and discuss what they have learnt since expressing these first general impressions, how best course-learnt skills should be applied in their final blog production, and how the grading scale should reflect this progress. Collaborative reflection on this subject takes place via Forum 5 . This year's grading criteria, agreed upon by the participants in the course and validated by the teacher, were as follows: Appearance/Design (7 points): Title /1 Theme / 2, Images/ Illustrations /3, Presentation of Authors / 1. Content and Reader Engagement (13 points: Quality of English /4, Style/Content Consistency /3, Solid References/ Arguments /3, Reader Engagement /3). Once these have been agreed upon, validated and published by the teacher, students are actually ready to create their own blogs (see appendix 5). The different groups use their chats to discuss technical details such as which site to use to create their blog, passwords, etc.

The first post on each blog is the text 'About Us' that students worked upon in the previous stage. Links to the different blogs (outside Moodle) are posted in Glossary 2 and students are encouraged to visit their peers' blogs and to comment on them.

The final activity entails one student from each group copying the link to their group's blog into the Moodle homework space. The teacher then manually collects all the links and pastes them into Forum 6, using the individual group setting, so that each group receives the blog link of a different group and the marking criteria grid in an attachment. The groups are given a week to discuss and agree upon a final mark for the blog of their peers that they have been assigned to evaluate (appendix 6).

\section{Teacher Feedback and Teacher/Student Interaction}

In accordance with the gradual development of learner autonomy over the year, the second-semester blogging online course contains NO mark generated by the teacher (appendix 2). This does not mean that the teacher is not present, for as Storch (2017: 71) reminds us, if online courses are to be successful, the teacher's role must be 'active' and I would add, be seen to be active by the students. The teacher wrote over 60 posts in the various forums including Creative Feedback Forum and Up-to-date Course Information Forum (both reserved for the teacher), Your questions Forum (for teacher and students) as well as reading and commenting on the student blogs. So, whilst the teacher is not required to mark student work, she is most certainly active! The teacher's main tasks are interacting with and accompanying learners on the road to increased learning autonomy, and facilitating the construction of a creative learning environment in which students feel confident to practise and improve their English language and blogging skills. Teacher/student feedback and interaction take several forms. In the early stages of the course, before the blogs are set up the teacher provides creative feedback and up-to-date course information in separate forums. As in the fiction-writing course, the creative feedback, posted by the teacher, is essentially a rewriting of and reaction to student texts, and constitutes an important element in the construction of group coherence, contributing as it does to the sense of "individual work becom(ing) part of a poetic, virtual whole, belonging simultaneously to all the writers, teacher and students alike" (Bouhmid 2019a: § 31). Students are encouraged not to contact the teacher privately by email but use the public forums to share their learning enquiries and doubts as well as their pleasure and enthusiasm, not only so that 
they can get used to writing in a semi-public sphere but also to ensure that information circulates, creating a real sense of belonging to a learning community.

Once the student blogs are up and running, the teacher leaves public comments on the student blogs (appendix 7). In addition, the teacher posts the links to all the student blogs on her own blog, encouraging students and followers of her blog to visit student blogs and comment on them. Whilst content-based feedback is provided in a public manner, form-based feedback is posted privately in a Moodle forum to which only group members have access.

\section{Assessment of programme and learning outcomes}

2019 was the first year that this course was introduced, and it ran until the beginning of May, so it is too soon (and out of the remit of this report) to provide other than some summary remarks. Firstly, course participation was basically stable between 35 and $45 \%$, which was encouraging (figure 1 ).

Figure 1: Student participation in course

The exceptions to this are the two activities of Glossary 2, in which students had to intervene three times during the course (posting texts prior to publishing and commenting on peers' texts) in order to obtain the participation points, and Forum 5 in which the grading criteria were decided. Regarding Glossary 2, the participation would have been on a par with the other activities if two rather than three interventions had been necessary in order to obtain the participation points; next year the procedure will be simplified. As for Forum 5, it may be that the lower participation in this activity was due to student reluctance with regards to involvement in the construction of grading criteria. However, given the general level of enthusiasm for the course, this is not the hypothesis favoured. It would seem more likely the result of the rather overbearing presence of one very voluble student. The teacher did not intervene until the grading forum discussion was closed, as had been announced beforehand. With hindsight it might have been better for the teacher to have moderated the discussion as it was ongoing, and this will be adjusted next year. Once the final grading criteria were validated and published by the teacher, no student queried them and all the groups applied them for peer evaluation. Students both expressed their pleasure, "It is as if I put myself in the shoes of the teacher, and it's cool" as well as their understanding of the usefulness of this activity "Put your finger on what is needed for a blog".

\section{Peer interaction}

On the whole, the course was very rich in peer interaction and has provided a considerable corpus of student writing which will be interesting at a later date to analyse. Nine out of 12 groups formed were active on the first chat session and the number of chat meetings ranged from 1 to 9 with the average time spent chatting per group being 138 minutes. Given that this was only one out of 10 possible interactive activities (which does not include the lesson time nor the setting up of their blogs), this would suggest that the time spent on this course by the students who participated regularly was doubtless considerably over 18 hours. However, when asked for feedback 
on the course, several students remarked on the difficulty of setting up a live chat meeting, due to living in different time zones and having different life/work rhythms. One student suggested (for following years) keeping the chat space for students who wish to use it, without linking it into participation points. Several groups said they had used social media platforms rather than the Moodle chat space. Despite this, the students who replied to the course survey seemed convinced that the collaborative aspect of the course and the interaction they had with their peers positively contributed to improving their English-language writing skills (appendix 8).

Ten of the 12 active groups used the wiki for text writing and editing, with one group producing 39 different versions of their vocabulary list and the text 'About Us'. The average number of versions per group was 14. All students who were active in producing a blog were successful in the course. Given the quantity and quality of the written interaction in English, it would seem that the mark is a fair reflection of student implication in the course and successfully valorised the diverse skills and experiences of this very diverse group of online students.

\section{Some concluding remarks}

Overall, students who participated regularly in the course and answered the student survey felt that course objectives were achieved (appendix 9). As one student so eloquently put it:

I learnt so much more in this year being in contact with my peers and always having a feedback when I needed it from my teacher, than when I had to stay so many hours in my English books and the informations flyed away from my head so fast. $^{3}$

21 It would be interesting at a later date to trace individual students' productions in order to establish to what extent their impressions are justified.

Regarding the technical aspect of the course, despite the fact that Moodle is a collaborative learning platform, it cannot be denied that (as far as version 3.1 is concerned) the platform is not all that efficient when it comes to setting up activities that require students to provide collaborative feedback and grading, and necessitates a certain amount of very time-consuming manual teacher interventions. One example of this is the workshop tool which, whilst working well for individual peer feedback and evaluation, is not designed for group feedback. Doubtless, future versions will address this sort of issue.

Even if the choice was made not to use the Moodle blog tool because of its various drawbacks, Moodle, as is hoped this piece has shown, can be used to teach students about blogging and function as a springboard to creating group blogs. The present course, while it can be improved, does seem to confirm the belief that the pedagogical use of blogging can increase learner autonomy not only in terms of requiring student choice concerning subject matter and honing transferable skills but also in terms of assuming authorship (Rivens Mompean). It could be added that blogging enables the development and legitimising of voice both personal and social, which is seemingly central to creativity and autonomy and without which language learning will remain a mere exercise in form. but also teacher attitudes to learning. Because of the sheer volume of texts produced by 
students in a multitude of different spaces, it is impossible for the teacher to follow all exchanges and to begin with this can be a rather bewildering experience for all involved. Students must learn to have confidence in their own abilities and those of their peers. They must grow into their increased learner autonomy and accept the responsibilities that come with this, including implication in their peers' learning. Teachers have to choose when and how best to intervene and respect learners' virtual spaces and voices whilst ensuring that course objectives are respected. However, as the student blogs show (Bouhmid 2019b) once this shift is embraced both by students and teachers alike, not only can the results be quite spectacular, but much fun can be had by all.

\section{BIBLIOGRAPHY}

BOUHMID, Alison. 2019a. "Diversity in creative writing workshops: The case of undergraduates studying English as a foreign language.” Cahiers de l'APLIUT 38/1. doi: 10.4000/apliut.7006. BOUHMID, Alison. 2019b. "Creative Blogging Course". On creativity and writing and teaching English as a foreign language. <www.alisonbouhmid.com/creative-blogging-course>. Accessed 28 April 2019. CHANIER, T. \& J. CARTIER. 2006. “Communauté d'apprentissage et communauté de pratique en ligne : le processus réflexif dans la formation des formateurs". Revue internationale des technologies en pédagogie universitaire, 3/3, 64-82.

ColLINI, Stefan. 2016. What are Universities for? London, New York: Penguin.

DE LAVERGNe, Catherine \& Pauline LIEB-STOREBJERG. 2009. "L'Utilisation d'un blog en formation universitaire. Quelle pédagogie « embarquer »?" Distances et savoirs 7/3, 399-419. Cairn.Info, $<$ https://www.cairn.info/revue-distances-et-savoirs-2009-3-page-399.html_. Accessed 28 April 2019.

GASS, Susan M. 1997. Input, interaction, and the second language learner. Mahwah, NJ: Lawrence Erlbaum Associates.

JONES, Rodney H. \& Jack C. RICHARD (eds.). 2016. Creativity in Language Teaching. Perspectives from Research and Practice. New York, London: Routledge.

KESSLER, G., D. BIKOWSKI \& J. BOGGS. 2012. “Collaborative writing among second language learners in academic web-based projects". Language Learning \& Technology, 16(1), 91-109.

HOLEC, Henri. 1981. Autonomy and Foreign Language Learning. Oxford, New York: Pergamon.

LITTLE, David, Leni DAM \& Lienhard LEGENHAUSEN. 2017. Language Learner Autonomy: Theory, Practice and Research. Bristol: Multilingual Matters.

MACKEY, A., R. ABBUHL \& S. GASS. 2012. "Interactionist approach". In S. Gass \& A. Mackey (Eds.), The Routledge handbook of second language acquisition (pp. 7-23). New York: Routledge. 
RIVENS MOMPEAN, Annick. 2010. "The development of meaningful interactions on a blog used for the learning of English as a Foreign Language”. ReCALL 22/3, 376-395. doi:10.1017/ s0958344010000200.

SARRÉ, Cédric \& Saghie SHARIFZADEH. Forthcoming. "La correction dans l'interaction entre apprenants d'une langue seconde”. In A. LEROUX, S. RAINERI \& M. SEKALI (Eds.), La correction en langue(s) / Linguistic correction/correctness. Paris: Presses universitaires de Paris Nanterre. STORCH, Neomy. 2013. Collaborative writing in L2 classrooms. Bristol, UK: Multilingual Matters. STORCH, Neomy. 2017. "Peer corrective feedback in computer-mediated collaborative writing". In Nassaji, H. \& E. Kartchava (eds.), Corrective Feedback in Second Language Teaching and Learning. Research, Theory, Applications, Implications. Routledge: New York, 65-79.

SWAIN, M., \& S. LAPKIN. 1998. "Interaction and second language learning: Two adolescent French immersion students working together". The Modern Language Journal, 82(3), 320-337.

TIGCHELAAR, M. \& C.CPOLIO. 2017. "Language-focused peer corrective feedback in second language writing”. In H. NASSAJI \& E. KARTCHAVA (Eds.), Corrective feedback in second language teaching and learning (pp. 97-113). New York / London: Routledge.

WIGGLESWORTH, G. \& N. STORCH. 2009. "Pairs versus individual writing: Effects on fluency, complexity and accuracy”. Language Testing, 26(3), 445-466.

\section{APPENDIXES}

\section{Appendix 1: $1^{\text {st }}$ Semester (Fiction writing) Course design and Evaluation}

\begin{tabular}{|c|c|c|}
\hline $\begin{array}{l}\text { SESSION } 1 \\
\text { Getting to Know Each Other }\end{array}$ & $1 / 10$ au $7 / 10$ & Forum 1 = 1 point \\
\hline $\begin{array}{l}\text { SESSION } 2 \\
\text { Who's Who }\end{array}$ & $08 / 10$ au $14 / 10$ & Forum $2=1$ point \\
\hline $\begin{array}{l}\text { SESSION } 3 \\
\text { Setting the Scene } \\
\text { Décrire les extérieurs }\end{array}$ & $\begin{array}{l}\text { 15/10 au 28/10 } \\
\text { (Dépôt de travaux 15-21/10 } \\
\text { Feedback } 22-28 / 10 \text { ) }\end{array}$ & $\begin{array}{l}\text { Writing Task } 1=4 \text { points } \\
\text { (Atelier d'écriture) }\end{array}$ \\
\hline $\begin{array}{l}\text { SESSION } 4 \\
\text { Setting the Scene } \\
\text { Décrire les intérieurs }\end{array}$ & $29 / 10$ au $4 / 11$ & Forum $3=1$ point \\
\hline $\begin{array}{l}\text { SESSION } 5 \\
\text { Show rather than Tell } \\
\text { L'implicite }\end{array}$ & $\begin{array}{l}\text { 5/11 au 25/11 } \\
\text { (Forum 5-11/11 } \\
\text { Dépôt de travaux 12-18/11 } \\
\text { Feedback 19-25/11) }\end{array}$ & $\begin{array}{l}\text { Forum } 4=1 \text { point } \\
\text { Writing Task } 2=10 \text { marks } \\
\text { (Atelier d'écriture) }\end{array}$ \\
\hline
\end{tabular}




\begin{tabular}{|l|l|l|}
\hline SESSION 6 & Forum $5=1$ point \\
Once Upon a Time & $26 / 11$ au 9/12 & $\begin{array}{l}\text { Forum } 6=1 \text { point } \\
\text { Forum } 7=1 \text { point }\end{array}$ \\
\hline SESSION 7 & $10 / 12$ au 23/12 & $\begin{array}{l}\text { Writing Task } 3=10 \text { marks } \\
\text { (Devoir à rendre) }\end{array}$ \\
\hline Flash Fiction & $17 / 12$ au 30/12 & Feedback $=1$ point \\
\hline Coursion 8 & & \\
\hline
\end{tabular}

Appendix 2: $2^{\text {nd }}$ semester (blogging) course design and evaluation

\begin{tabular}{|c|c|c|}
\hline $\begin{array}{l}\text { STAGE } 1 \\
\text { Introductions } \\
\text { What exactly is a blog? }\end{array}$ & $4 / 02$ au 10/02 & $\begin{array}{l}\text { Forum } 1 \text { (Me and Blogging })=3 \text { points } \\
\text { Glossary } 1=2 \text { points }\end{array}$ \\
\hline $\begin{array}{l}\text { STAGE } 2 \\
\text { Features of Blog Writing }\end{array}$ & $11 / 02$ au $17 / 02$ & Forum $2(\mathrm{Good} / \mathrm{bad}$ blogs $)=3$ points \\
\hline $\begin{array}{l}\text { STAGE } 3 \\
\text { Different sorts of Blogs }\end{array}$ & $18 / 02$ au $24 / 02$ & Forum 3 (Different blogs) $=3$ points \\
\hline $\begin{array}{l}\text { STAGE } 4 \\
\text { Collaborative Writing } \\
\text { From Me to Us }\end{array}$ & $25 / 02$ au $10 / 03$ & $\begin{array}{l}\text { Glossary } 2 \mathrm{a} \text { About } \mathrm{Me}=2 \text { points } \\
\text { Forum } 4 \text { (Choice of Subject Matter) }=3 \\
\text { points }\end{array}$ \\
\hline $\begin{array}{l}\text { STAGE } 4 \text { bis } \\
\text { Collaborative Writing } \\
\text { Continued. } \\
\text { From Me to Us }\end{array}$ & $11 / 03$ au $24 / 03$ & $\begin{array}{l}\text { Chat } 1=3 \text { points } \\
\text { Wiki }=10 \text { points } \\
\text { Glossary } 2 \mathrm{~b} \text { About } \mathrm{Us}=1 \text { point }\end{array}$ \\
\hline $\begin{array}{l}\text { STAGE } 5 \\
\text { Public Writing } \\
\text { Without Forgetting Them }\end{array}$ & $25 / 03$ au 31/03 & Forum 5 (Grading Criteria) $=3$ points \\
\hline $\begin{array}{l}\text { STAGE } 6 \\
\text { Blog Off }\end{array}$ & $1 / 04$ au $14 / 04$ & $\begin{array}{l}\text { Chat } 2=3 \text { points } \\
\text { Glossary } 2 \mathrm{c} \text { Blog Link }=1 \text { point }\end{array}$ \\
\hline $\begin{array}{l}\text { STAGE } 7 \\
\text { Blogduggery }\end{array}$ & $\begin{array}{l}\text { 15/04 au 28/04 } \\
\text { Workshop: } \quad \text { phase } \\
\text { 15/04-21/04 } \\
\text { Workshop: } \quad \text { phase } \\
\text { 22/04-28/04 }\end{array}$ & $\begin{array}{l}\text { BLOG }=20 \text { points } \\
\text { Survey }=3 \text { points }\end{array}$ \\
\hline
\end{tabular}




\section{Appendix 3: One example of a student post (verbatim) in Forum 3}

“This blog's article is written in a very formal language. Usually, bloggers tend to connect with their readers (using either slang, emoji, or colloquial language). Yet this author's chose a purely informative approach: he first quickly presents the place from an historical and biological point of view before referring to touristic pieces of information, which are the heart of the article.

Sentences are all grammatically well-constructed, some scientific words come up (such as "sediment") and the tone is obviously purely formal. It does not include any subjectivity, personal anecdotes or impressions which makes this blog article look like a report."

Appendix 4: Stage 5 of online blogging course. Public Writing and Grading Criteria

As we have seen one of the important features of blogging is that it concerns text that is posted on the internet, that is to say text that exists within the public domain. This means that anyone will be able to read your posts. People will also be able to comment on them.

I think one piece of advice worth remembering is that before putting anything out there (and this includes emails!) you should always ask yourself the question, 'Would I mind if this text was read or seen by anybody in a different context.' If the answer is yes then don't post. Personally, I would also suggest never reacting or posting live. Leave yourself a day or two to mull (think) things over.

Reread before you post, this will help you to avoid stupid mistakes and typing errors. (The preparatory work that we are doing is to help you correct texts before posting). Go back to Glossary 2. Each student should read the text (About Us and our Blog) of the student that comes after him/her in the glossary and comment on them keeping the following questions in mind:

1) Do you get a clear idea of the people writing the blog?

2) Does the text make you want to read the blog?

3) What are the text's strong points?

4) What would you suggest working on / developing? For instance are there any points that are unclear or even missing?

5) You can comment on / correct the English.

In Stage 2 you answered the question, 'What makes a good/bad blog'. Before actually creating your own we are going to go back to this and from it try to write a feedback grid which will provide grading criteria. Reread forum 2. Now use Forums 5 (according to your groups) to work out your grading criteria that we can use to give blogs a grade out of 20 .

\section{Appendix 5: Stage 6 of online blogging course}

In this stage you are actually going to set up your blog.

Using your Chat 2 Creating our Blog you must decide together on which blog platform you are going to use for your blog (so once again the first thing you need to do is to set up a time when you can all meet and chat live). 
You can choose whatever platform you wish to set up your blog as long as it is FREE and we can all access it.

You might want to read through the following post from which recommends ten free blogging platforms.

I have tested www.blogger.com which is easy-to-use but you will need to create google email addresses if you don't already have them.

I have several friends and colleagues who use wix and highly recommend it, assuring me that it is very easy to use.

For my own site I use wordpress but I wouldn't recommend this unless you are used to using online tools because it's quite tricky to get the hang of.

Lixia, Webnote, Unblog, Eklablog are other possibilities that people have either mentioned to me or I have read about.

\section{Checklist of some points you need to decide upon together:}

Usernames

Password (all members of group probably need to use the same so that they can edit the blog)

Theme

Appearance...what images are you going to use?

Headers, footers, sidebars, tags...

Title (if you haven't already decided this)

Set up the possibility to receive comments BUT make sure that they are sent to you via email for moderation before they are published.

\section{Appendix 6: One partial example of student interaction}

Re: Group two, evaluation of peer's blog

par Student A, dimanche 28 avril 2019, 20:07

Hello dear peers...

So, I tried to fill the marking grid with coherence and also keeping on mind all the difficulties that we met creating our blog.

I think that they made a good job and I like the final result. We have to remember that a blog is never completely finished and it is aslo the interesting and exciting thing that make this experience great!

So, for my part, a part of the fact that I would chose an other type and style of writing (I think they are too much formal, autobiographical and cold) to make their articles more attracting and exciting! However, it can also be their personal choice, so I respect it. For the rest, I like the layout and as I already told many times, I love the topic.

This is my grid:

Title: 1

Attractive theme: 2 
Images/Illustrations 3

Authors clearly presented 1

Quality of English: 4

Style/content consistency: 1,5

Solid references/arguments: 2

Reader engagement: 2,5

Re: Group two, evaluation of peer's blog

par Student C, dimanche 28 avril 2019, 20:22

Hello Student A! Thanks for your participation! I agree with you generally. The only thing I don't follow you, it's for the points that you removed for their style and their arguments. The style can be discussed and as you said it's their choice: we like it or not. But there are no faults of taste objectively... Then, for their arguments, as it's biographies of famous people, I think they have checked their informations on the net or an encyclopedia! So, we can't take away points for the fragility of their arguments... I propose:

Title: 1

Attractive theme: 2

Images: 3

Authors clearly presented: 1

Quality of English: 4

Style: 2

Solid references: 3

Reader engagement: 2;5

Re: Group two, evaluation of peer's blog

par Student B, dimanche 28 avril 2019, 20:23

Hi Student A and Student C,

It is ! The last course ! This blog qbout the question of the feminist is very interesting, but I agree with you Student A. They haven"t add articles and too theoritical for me. I'm searching on the net about this subject and I know there is difficult to defend the women in this century. Okay, but there were a men also, it' was a start of progress. Feminist, eguality, liberty, it's a battle in the worlwide, not the women battle only. So, my grid :

Title : 1

Attractive theme : 2

Image : 3

Autor clearly presented : 1

Quality of English : 4

Style/ content consistency : 2

Solids references : 3 
Reader engagement : 1.5

Total : 17.5

Re: Group two, evaluation of peer's blog

par Student A, dimanche 28 avril 2019, 20:30

Ok student C, you are true, maybe I was too much strict, I think your grid could be the definitive one!

Appendix 7 : An example of public student/teacher interaction on blog

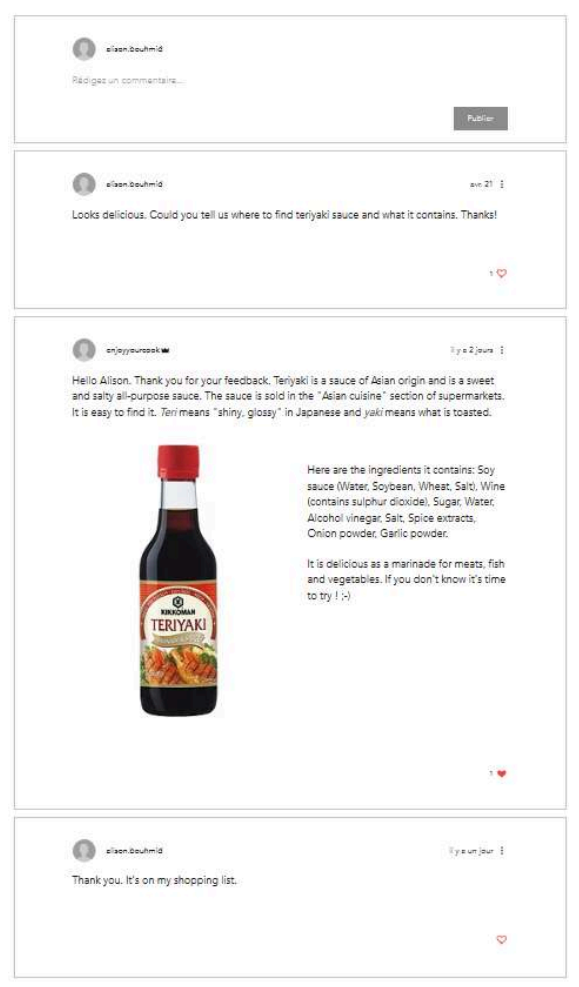

Appendix 9: Student feedback in course survey concerning peer interaction (in percentages of respondents)

\begin{tabular}{|l|l|l|l|l|}
\hline On a scale of 1 to 4 answer the following questions regarding course objectives & 1 & 2 & 3 & 4 \\
\hline To what extent did you enjoy this course? & $4 \%$ & $15 \%$ & $37 \%$ & $44 \%$ \\
\hline To what extent did the course improve your English writing skills? & $7 \%$ & $11 \%$ & $56 \%$ & $26 \%$ \\
\hline To what extent did the course develop your digital literary skills? & $0 \%$ & $22 \%$ & $44 \%$ & $33 \%$ \\
\hline To what extent did the course exercise your creativity? & $0 \%$ & $15 \%$ & $30 \%$ & $56 \%$ \\
\hline To what extent did the course develop your autonomy as a learner? & $7 \%$ & $11 \%$ & $41 \%$ & $41 \%$ \\
\hline $\begin{array}{l}\text { To what extent did the course develop your ability to interact with your } \\
\text { fellow learners? }\end{array}$ & $4 \%$ & $26 \%$ & $26 \%$ & $44 \%$ \\
\hline
\end{tabular}


To what extent did the course develop your ability to provide positive feedback?

\section{NOTES}

1. WebCT (World Wide Web Course Tools), a platform originally developed at the University of British Columbia in 1996 by computer scientist Murray Godberg, was designed to facilitate the creation of web-based learning environments.

2. «La conception de l'apprentissage que nous adoptons dépasse largement l'acquisition pure et simple de savoirs techniques ou théoriques, et s'incarne dans une nouvelle façon de percevoir et de comprendre sa relation au monde et aux savoirs ». Our translation.

3. Verbatim student comment.

\section{INDEX}

Keywords: blended course, human science programme, EAP, teaching practice

Mots-clés: anglais universitaire, apprentissage mixte, compte rendu d'expérience, formation en sciences humaines

\section{AUTHOR}

\section{ALISON BOUHMID}

Paul Valéry University in Montpellier. alison.bouhmid@univ-montp3.fr 